\title{
Research on Curriculum Reform of Physical Education Major in Colleges and Universities
}

\section{Chao Tian}

Dalian Maritime University, Dalian, Liaoning, 116023

Keywords: curriculum reform; physical education; college education

\begin{abstract}
Physical education is one of the components of college education and cultural system and an important aspect of completing college education tasks. The task of college physical education has been deepened by learning technology, strengthening physical fitness, learning to learn, learning knowledge, learning to communicate, learning to be a human being, and realizing the conceptual reconstruction of college sports in terms of goals, systems, processes, and effects in the traditional sense. Paying attention to the promotion of physical education for the healthy development of students' physical and mental health, getting rid of the content of traditional teaching mode that does not adapt to the reform, paying attention to the sports needs of students, and setting up the physical education curriculum system centering on the healthy growth of people is the reform task faced by college physical education curriculum. In the reform of college physical education curriculum, it is necessary to provide physical education courses that meet the requirements of students and characteristics of schools according to objective reality and development needs.
\end{abstract}

\section{Introduction}

Physical education is an important part of the university education. It is not only a key subject to train students' physical and will quality, but also an important subject to achieve comprehensive quality education. However, due to the influence of the traditional education model, many students lack basic attention to the physical education discipline, which makes the Chinese college students show an unbalanced development state, which is very unfavorable for the future development of students. In order to change the current teaching situation of the physical education discipline, students can give full attention to the physical education curriculum, and it is imperative to realize the reform of the university physical education curriculum.

\section{Reform and Development Trend of College Physical Education}

In the process of college physical education reform, the effective transformation of the concept of physical education curriculum is particularly important for the development of university sports. In order to realize the reform of the physical education curriculum, it is necessary to have the correct guiding ideology as a guide, and the concept of physical education curriculum is the guiding ideology. With the continuous development of globalization education, the teaching philosophy of college sports in China must be kept up to date, thus achieving the success of college physical education in China. Under this background, the major Colleges in China have realized the effective transformation of the teaching concept of physical education curriculum. Physical education is no longer a simple "physical fitness". The comprehensive physical education model integrating physical education and humanities education has become The main body of school education. The effective construction of the physical education teaching model is the main work content of the university physical education curriculum reform. Under the background of university sports reform, the construction of college physical education teaching mode in China has achieved good results, including Peking University's "completely open" physical education teaching mode, Tsinghua University's "three independent" physical education teaching mode and Shenzhen University's The "club-style" physical education model is an advanced representative in the context of the reform of 
university physical education curriculum. These teaching modes can not only complete the teaching objectives of physical education curriculum, but also realize the full mobilization of students' sports interest, meet the needs of different students for different sports learning content, improve the teaching quality of college sports, and improve students' The independent participation of physical education has realized the cultivation of students' physical quality, thus effectively completing the training objectives of college physical education curriculum.

Before the reform of the physical education curriculum, the content of the physical education curriculum of most universities was relatively simple, and the comprehensive quality training of the students was completely unable to meet the requirements. After the reform of physical education, the schools have realized the reform of the content of physical education, and can adjust the content of physical education according to the characteristics of the school and the actual situation of the students. The evaluation of college physical education curriculum is an important part of the physical education curriculum teaching, and its influence on the teaching effect of physical education curriculum is also very huge. In the context of the reform of university physical education curriculum, many universities have changed their own methods of physical education curriculum evaluation. The traditional era of evaluation of physical education based on the level of competition has passed. The comprehensive physical education evaluation model with students' learning attitude, learning process performance, learning progress and learning effect as the main content has become the main method of college physical education evaluation. The emergence of this kind of teaching evaluation model can not only help students achieve the goal of physical education as soon as possible, but also affirm the students' attitudes and efforts in the process of physical education, and further help students build confidence in sports learning and comprehensive physical education for students. The cultivation provides objective conditions.

\section{The Role of College Physical Education in Higher Education}

University physical education belongs to the field of higher education and bears the important mission of accomplishing the goal of higher education. On the general education platform of talent cultivation, university sports has four meanings. First of all, university sports are conducive to the physical and mental health of students. Secondly, the educational process of university sports is the process of cultural education. Through a series of studies, training and practice, students are educated by relevant sports cultures to improve their overall quality. A series of physical education activities achieve the purpose of spiritual education, so that students' self-confidence, courage, tenacity, hard work, cooperation and other qualities are perfected. Fourth, cultivate applied talents related to sports. The important goal of college physical education is to educate students to be human beings, emphasize the cultivation of students' psychological quality, and improve students' social adaptability. In the process of college physical education, we must adhere to the principle of people-oriented, and exercise activities such as sports participation, sports skills, physical health, mental health, and social adaptability as an organic connection, and play a special role in cultivation and education. Features. Based on the concept of general education, we believe that the university physical education system is a three-dimensional structure composed of the humanistic principle layer, the scientific principle layer and the behavior mode layer. For a long time, people's attention to college physical education has only focused on the visible part of the iceberg, while ignoring the invisible part of the decision below. The concept of football coach Milu's attitude to everything succinctly reveals the value of the software below the iceberg. It can be seen that the essence of university physical education that explores the integration of science and humanity is to integrate humanity and materiality in order to better promote the all-round development of college students. Today, integrating the educational goals of university sports into the scope of general education will definitely enhance the function and effect of university physical education curriculum. General education has a wide range of connotations, and university sports is only part of it; and this function can not be fully realized through physical education classroom teaching, but also includes extracurricular sports, sports clubs, and high-level sports teams. All aspects of university physical education are coordinated and fully implemented to better serve general education and achieve the 
goal of general education.

\section{Curriculum Reform of China's Physical and Health Education}

Before 2000, China's university public physical education curriculum was called "Sports and Health", which is the prototype and foundation of the "Sports and Health Curriculum" curriculum reform. After the new round of curriculum reform, China's sports and health curriculum changed the original "content standard" to "course content". First propose the course objectives, then list the course content required for the corresponding requirements of the target, and lead the content with the goal. The content of the course is arranged by each school according to its own situation. There is no specific hardening rule, combined with different levels of student status, the side of the course content. The key points are also different: Levels 1 and 2 are mainly to stimulate and protect students' sports interests, focus on developing students' basic physical activity ability, and carry out various forms of competition activities; level three stages to form and develop students' sports hobbies, Appropriately reduce the learning content, focus on one or two sports in each type of project; Level four requires students to focus on one or two sports skills, and requires skilled use of the sports skills.

In the past teaching evaluation of physical education curriculum, due to the influence of disciplinaryism and competitive sports competitions, the evaluation content is more about the assessment of physical fitness and the assessment of knowledge and skills. The new curriculum reform starts from the actual situation of individual students and combines the physical and psychological aspects of students. The three health views of the society have increased the assessment of attitude and participation and the evaluation of affection and cooperation on the basis of the original, and established an evaluation target system that is suitable for it. The curriculum evaluation method includes the combination of qualitative evaluation and quantitative evaluation, the combination of relative evaluation and absolute evaluation, and the combination of formation evaluation and final evaluation, combination of level evaluation and overall evaluation, and combination of physical evaluation and physical evaluation. The combination of self-evaluation and mutual evaluation, changing the previous evaluation and teaching synchronization, can not achieve the shortcomings of timely feedback of evaluation results, and promote the more comprehensive development of students. In the specific evaluation method, there are various evaluation methods such as observation, oral evaluation, test, and skill assessment. Presenting diversified trends in the evaluation subjects, including teacher evaluation, student evaluation, student self-evaluation, student mutual evaluation, etc., allowing students to participate in the evaluation process, reflecting the student's subject status while improving students' interest in learning, changing the previous focus only The wrong way of teacher evaluation.

At present, in the reform of physical education, the goal of "health first" is the form of the guideline. Most students can't master one or two sports skills when they graduate, let alone the habit of developing "lifelong sports". Physical education teaching thoughts, teaching content and teaching mode, and even unified national exercise standards and examination forms, Colleges across the country can not effectively combine the actual situation of the school, thus forming a mechanically rigid physical education pattern, making college physical education teaching too disciplined and uniform Students are less motivated to learn. Physical education emphasizes physical quality and competitive sports, focuses on sports technology, and neglects other aspects, such as psychological, social adaptation, student innovation, different needs, physical fitness of individual students and so on. In the assessment, it is impossible to treat them differently. Repeatedly training students is difficult to learn and use. The more serious problem is that the school does not invest enough in sports equipment and equipment in sports facilities, which affects students' participation in physical exercise.

\section{Conclusion}

Under the background of comprehensive quality education, the reform of college physical 
education curriculum has played an important role in the development of physical education in China and the improvement of college physical education. Although the college physical education teaching in China has experienced a period of low valley, with the implementation and implementation of the overall quality teaching goal, the reform of college physical education in China will inevitably bring university physical education into a new period of vigorous development. In the process of reform, in addition to the realization of the teaching objectives, teachers must also establish the status of students in physical education, improve students' emphasis on physical education, and make sports their basic skills. While the development of college physical education provides subjective guarantees, it provides conditions for the cultivation of students' overall quality.

\section{References}

[1] Yang Wenxuan, Zhang Xiqian. Implementation of the physical and health curriculum under the new normal [J]. Physical Education Journal, 2015, 22(5): 2.

[2] Hu Hanxing, Pan Shaowei. On the construction and implementation of the physical education and health curriculum under the ecologicalist curriculum concept [J]. Journal of Nanjing Institute of Physical Education, 2009, 23(1): 88 - 89.

[3] Zhang Yueheng. Reform and analysis of the goals of physical education curriculum in Colleges in China [J]. Hua Zhang, 2011 (32): 249.

[4] Liu Wei. The Reform and Reconstruction of the Objectives of School Physical Education Curriculum in China--On the Standards of Physical Education and Health Courses [J]. Journal of Beijing Sport University, 2005, 28(11): 1529 -1531.

[5] Zhuo Mengyao. The Reform of Physical Education and Health Curriculum in China_—Based on Comparative Analysis of American SPARK Courses [J]. Journal of Sports Adult Education, 2015, 31(2): $24-27$. 